\title{
Recoupling the Na-K Pump
}

\author{
JOHN R. SACHS \\ From the Department of Physiology, Yale University School of Medicine, \\ New Haven, Connecticut 06510
}

\begin{abstract}
A в S T RACT Human red blood cells display under appropriate circumstances a ouabain-sensitive $\mathrm{K}-\mathrm{K}$ exchange when the flux measurements are made using radioisotopes. Such an exchange complicates measurements of the coupling of $\mathrm{Na}$ outflux to $\mathrm{K}$ influx in cells which are partially depleted of energy sources by deprivation of glucose since the $\mathrm{K}-\mathrm{K}$ exchange has been found to be increased in depleted cells. When the measurements of flux are made by estimating net cation movements chemically, it is found that glucose deprivation results in a fall in both ouabain-sensitive $\mathrm{Na}$ outflux and ouabain-sensitive $\mathrm{K}$ influx. Since both fluxes fell in concert, there is no reason for believing that the fluxes are not coupled or that the source of ATP for the Na outflux is different from that for the $\mathrm{K}$ influx.
\end{abstract}

\section{INTRODUCTION}

Since the first demonstration that the $\mathrm{Na}$ outflux from human red blood cells is reduced when extracellular $\mathrm{K}$ is removed (1), a considerable amount of evidence has accumulated to support the concept that the active $\mathrm{Na}$ outflux and active $\mathrm{K}$ influx are coupled in the sense that movement of $\mathrm{Na}$ out of the cell through the pump must be accompanied by a simultaneous movement of $\mathrm{K}$ into the cell. It has been demonstrated that the relation beween the magnitude of the active $K$ influx and the extracellular $\mathrm{K}$ concentration is the same as the relation between the active $\mathrm{Na}$ outflux and the extracellular $\mathrm{K}$

This work was performed during the tenure of an Established Investigatorship of the American Heart Association, and was supported by U. S. Public Health Service Grants AM 13981 and HE 09906, and by National Science Foundation Grant GB 18924.

Received for publication 10 August 1972 and in revised form 12 September 1972. concentration (2), and that both the active $\mathrm{Na}$ outflux and $\mathrm{K}$ influx increase as the intracellular $\mathrm{Na}$ concentration is increased (3). Careful measurements have shown that, for every three $\mathrm{Na}$ ions transported out of the cell, two $\mathrm{K}$ ions are transported into the cell, and one ATP molecule is split $(3-5)$.

In a recent report, Feig, Segel, Shohet, and Nathan (6) state that, when human red cells are starved for short periods of time, the ouabain-sensitive $\mathrm{Na}$ outflux falls but the ouabain-sensitive $\mathrm{K}$ influx is little affected. They point out that, in the starved red cells, glyceraldehyde-3-phosphate is depleted and hence little ATP is formed by the phosphoglycerate kinase $(P G K)^{1}$ reaction. They suggest that ATP formed by this reaction is preferentially used as the source of energy for the $\mathrm{Na}$ outflux. They further suggest that, since 2,3-diphosphoglycerate (2,3-DPG) remains high for a time, there is sufficient substrate for the pyruvate kinase reaction and ATP from this source serves as the source of energy for the active $\mathrm{K}$ influx. If it is true that the energy source for the active $\mathrm{Na}$ outflux and active $\mathrm{K}$ influx is not the same, then the two fluxes must be independent and the evidence that they are coupled must be fortuitous.

It is possible, however, that a different explanation might be found for the observations of Feig et al. (6). In their studies, the measurements of the $\mathrm{Na}$ and $\mathrm{K}$ fluxes were made using the radioactive isotopes ${ }^{24} \mathrm{Na}$ and ${ }^{28} \mathrm{~K}$. Under these circumstances, the ouabain-sensitive outflux of ${ }^{24} \mathrm{Na}$ and influx of ${ }^{42} \mathrm{~K}$ will include not only the active outflux of $\mathrm{Na}$ and influx of $\mathrm{K}$, but also the ouabain-sen-

${ }^{1}$ Abbreviations used in this paper: 2,3-DPG, 2,3-diphosphoglycerate; FDP, fructose 1,6-diphosphate; GAPDH, glyceraldehyde- $P$-dehydrogenase; $\mathrm{K}_{\mathrm{c}}$, intracellular $\mathrm{K} ; \mathrm{K}_{\mathrm{o}}, \mathrm{K}$ in extracellular fluid; $\mathrm{Na}_{e}$, intracellular $\mathrm{Na}$; PCMBS, parachloromercuribenzenesulfonic acid; PGK, phosphoglycerate kinase; triose-P, triose phosphate. 
TABLE I

Effect of Intracellular $K$ Concentration $\left(K_{c}\right)$ on the OuabainSensitive K Influx in Cells with Very Low $\mathrm{Na}$ Cioncentrations $\left(N a_{c}\right)$

\begin{tabular}{cccc}
\hline & & $\begin{array}{c}\text { Ouabain-sensitive } \\
\mathrm{K} \text { influx } \\
\text { (mean } \pm \mathrm{SE} ; n=4)\end{array}$ & $\begin{array}{c}\text { Ouabain-sensitive } \\
\text { Na outflux } \\
\text { (mean } \pm \mathrm{SE} ; n=4)\end{array}$ \\
\hline \multicolumn{2}{l}{$\begin{array}{l}\text { mmoles/liter } \\
\text { erythrocytes }\end{array}$} & \multicolumn{3}{c}{ mmoles/liter er ythrocytes, $1 \mathrm{hr}$} \\
1.2 & 89.1 & $0.445 \pm 0.015$ & $0.022 \pm 0.003$ \\
1.2 & 0.9 & $0.026 \pm 0.003$ & $0.091 \pm 0.004$
\end{tabular}

$\mathrm{Na}_{\mathrm{c}}$ and $\mathrm{K}_{\mathrm{c}}$ were altered by exposure to PCMBS solutions containing glucose $5 \mathrm{mM}$, and dithiothreitol solutions containing $(\mathrm{mM})$ : glucose 5 , adenine 3 , and inosine 2 . The bulk of the cation in the low $\mathrm{K}_{\mathrm{o}}$ cells was made up of choline. The measurements of $\mathrm{K}$ influx were made in glycylglycine buffered $\mathrm{MgCl}_{2}$-sucrose solutions with $\mathrm{K}_{0} 0.67 \mathrm{mM}$, and the $\mathrm{Na}$ outflux measurements in the same solution except that $\mathrm{K}_{0}$ was $4.0 \mathrm{mM}$.

sitive $\mathrm{Na}-\mathrm{Na}$ and $\mathrm{K}-\mathrm{K}$ exchange (7-9). If, in the starved cells, the magnitude of the $\mathrm{K}-\mathrm{K}$ exchange increases as the magnitude of the active $\mathrm{K}$ influx decreases, one might expect that the total ouabain-sensitive ${ }^{42} \mathrm{~K}$ influx might remain unchanged. In the starved cells used by Feig et al. (6), it would be expected that ATP levels fall and inorganic phosphate levels rise as phosphorylated intermediates are broken down; these have been found to be conditions which increase the magnitude of the $\mathrm{K}-\mathrm{K}$ exchange (7-9).

The present paper reports the results of experiments designed to determine whether the active $\mathrm{Na}$ outflux and active $K$ influx decrease to the same extent in starved cells in which $\mathrm{K}-\mathrm{K}$ exchange cannot occur.

\section{METHODS}

The solutions used, manipulation of the cells, procedures used for the measurement of unidirectional $\mathrm{K}$ influx and $\mathrm{Na}$ outflux, and the methods used for the measurement of intracellular $\mathrm{Na}$ and $\mathrm{K}$ concentrations have been described (10). Purified choline chloride was obtained from Hoffman-Taff, Springfield, Mo. and was not further processed.

Alteration of intracellular cation concentrations was accomplished by a modification of a method described by Garrahan and Rega (11). Washed cells were suspended at about $5 \%$ hematocrit in a solution containing $(\mathrm{mM})$ : $\mathrm{PO}_{4} 3.4, \mathrm{Mg}^{++}$1.0, parachloromercuribenzenesulfonic acid (PCMBS) 0.1, $\mathrm{C1}^{-} 147$, glucose 10 , and varying concentrations of $\mathrm{Na}, \mathrm{K}$, and choline to make up a total of $150 \mathrm{mM}$. Sucrose was added at concentrations varying from 0 (all choline solutions) to $55.6 \mathrm{mM}$ (choline-free solutions) to maintain constant cell volumes. In some cases adenine and/or inosine were included. The suspensions were incubated at $4^{\circ} \mathrm{C}$ for $36 \mathrm{hr}$, and the solutions were changed every $12 \mathrm{hr}$. At $36 \mathrm{hr}$, the cells were separated from the solutions and resuspended in a solution identical to the PCMBS solution except that PCMBS was omitted and dithiothreitol $2 \mathrm{mM}$ was included. The cells were incubated in this solution for $1 \mathrm{hr}$ at $37^{\circ} \mathrm{C}$, separated from the solution, washed three times in $\mathrm{MgCl}_{2}$ solution $(107 \mathrm{mM})$, and used as appropriate.

Glycolytic intermediates were estimated by enzymatic reactions which result in the stoichiometric oxidation of $\mathrm{NADH}$; NADH concentration was measured fluorometrically (12). Neutralized $12 \%$ perchloric acid extracts of red cell suspensions were used for the determinations. ATP was determined with glyceraldehyde- $P$-dehydrogenase (GA$\mathrm{PDH})$ and PGK; 2,3-DPG with GAPDH, PGK and $P$-glycerate mutase; and fructose 1,6-diphosphate + triose phosphate (FDP + triose-P, reported as equivalent concentration of triose-P) with GAPDH, triose-P isomerase and aldolase.

\section{RESULTS AND DISCUSSION}

The existence in human red blood cells of a ouabain-sensitive $\mathrm{K}$ outflux which, in $\mathrm{Na}$-free solutions, depends on the presence of $K$ in the extracellular solution $\left(K_{0}\right)$ is clear evidence for a ouabain-sensitive $\mathrm{K}-\mathrm{K}$ exchange in these cells $(8,9)$. If there is a ouabain-sensitive $\mathrm{K}-\mathrm{K}$ exchange, it should be possible to demonstrate a ouabainsensitive $\mathrm{K}$ influx which is independent of intracellular $\mathrm{Na}(\mathrm{Nac})$, but does depend on intracellular $\mathrm{K}\left(\mathrm{K}_{\mathrm{e}}\right)$. Post and Sen (7) found a ouabain-sensitive $K$ influx in cells with $\mathrm{Na}$ e reduced so low as to eliminate any ouabain-sensitive $\mathrm{Na}$ outflux; this influx did not occur in inorganic phosphate-free cells. To demonstrate that this $\mathrm{K}$ influx in $\mathrm{Na}$ free cells is a $\mathrm{K}-\mathrm{K}$ exchange, it is necessary to show that it depends on $\mathrm{K}_{\mathrm{c}}$. An experiment designed to show such a dependence is summarized in Table $I$. Cells were prepared with very low $\mathrm{Nac}_{\mathrm{c}}$; half had high concentration $K_{e}$, and half were almost $\mathrm{K}$-free. The ouabain-senstive $\mathrm{K}$ influx was much higher in the cells containing $\mathrm{K}$ than in the $\mathrm{K}$-free cells. The $\mathrm{K}$ influx could not have been in exchange for a $\mathrm{Na}$ outflux since the ouabain-sensitive $\mathrm{Na}$ outflux in these cells was very small. The simplest explanation for a ouabain-sensitive $\mathrm{K}$ outflux dependent on $\mathrm{K}_{0}$ and a ouabain-sensitive $\mathrm{K}$ influx dependent on $\mathrm{K}_{\mathbf{c}}$ is the mechanism of $\mathrm{K}-\mathrm{K}$ exchange diffusion (13).

Since K-K exchange diffusion is a phenomenon which is seen only with the use of radioisotopes (13), it cannot complicate the measurement of net cation fluxes. Therefore net changes of $\mathrm{Na}$ and $\mathrm{K}$ were measured in cells which were altered to contain very low concentrations of $K_{c}$ (to increase the reliability of the determinations) and slightly high concentrations of $\mathrm{Na}_{c} ; \mathrm{Na}$ and $\mathrm{K}_{\mathrm{o}}$ in the solutions in which the measurements were made were chosen so that the cation gradients were small and the ouabain-insensitive fluxes minimal. One group of cells (repleted cells) had fairly normal concentrations of FDP + triose $P$, and the other group had low concentrations; the ATP and 2,3-DPG content of both groups was about normal. During the measurement of cation fluxes, the repleted cells were incubated in solutions containing glucose, and the depleted cells in glucose-free solutions. 
TABLE II

Ouabain-Sensitive Na Loss and K Gain in Low $K_{c}$ Cells

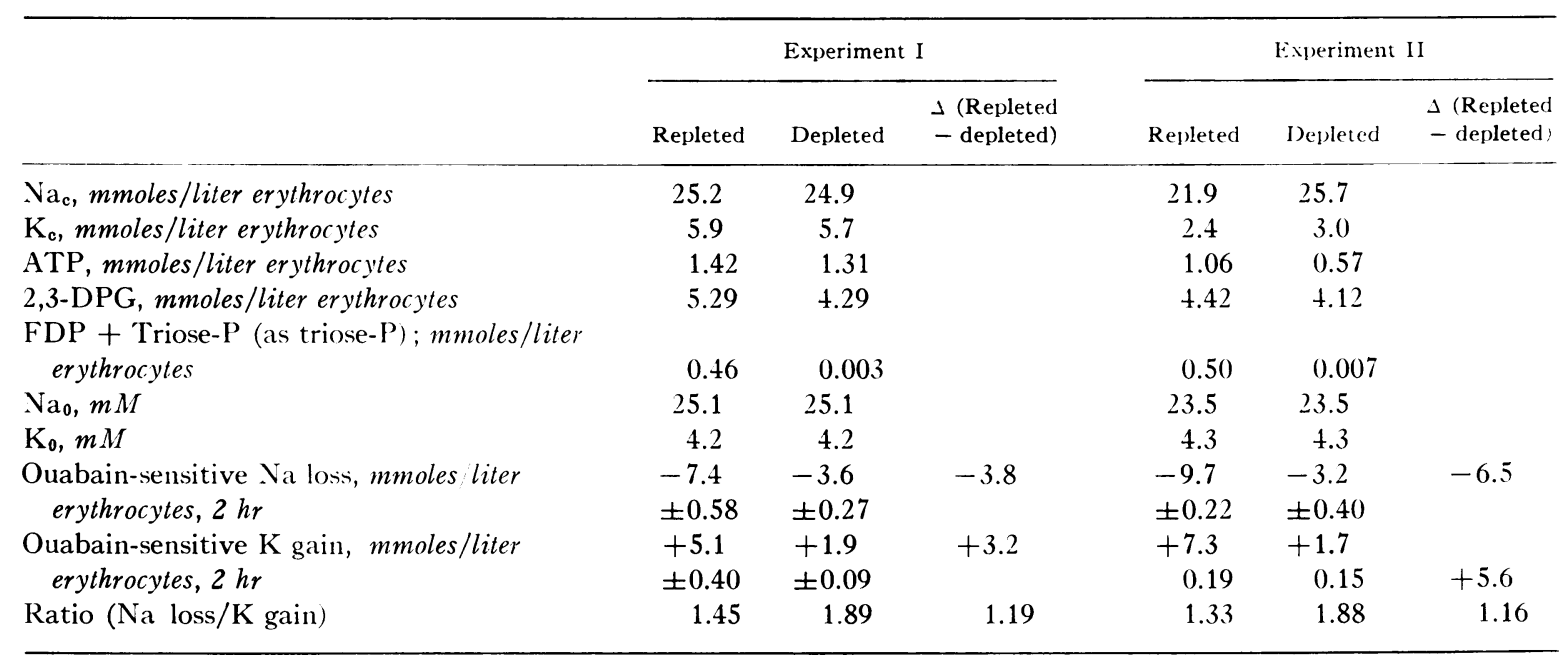

Red cell cation contents were altered by incubation in PCMBS solutions. In experiment I, the PCMBS solution contained $(\mathrm{mM}):$ glucose 10 , adenine 2 , and inosine 0.5 ; in experiment II the PCMBS solution contained (mM): glucose 10 and adenine 2 . In each case, the repleted cells were incubated in dithiothreitol solutions containing ( $\mathrm{mM}$ ): glucose 10 and inosine 1; the depleted cells were incubated in dithiothreitol solutions free of substrate. The values of $\mathrm{Na}_{\mathrm{c}}, \mathrm{K}_{\mathrm{c}}$, ATP, 2,3-DPG, and FDP + Triose P were those at the start of the experiment. The bulk of the intracellular cation was choline. The solutions in which the repleted cells were incubated for measurement of cation fluxes contained glucose $10 \mathrm{mM}$, and the depleted cells were incubated in glucose-free solutions. The bulk of the electrolyte in the solution was choline chloride. Samples for determination of cation content were taken $15 \mathrm{~min}$ and $2 \mathrm{hr}$ and 15 min after the cells were added to the solution; incubation was carried out at $37^{\circ} \mathrm{C}$. The values for the cation fluxes are means $\pm \mathrm{SE}$, $n=6$.

Table II presents the ouabain-sensitive net changes in $\mathrm{Nac}$ and $\mathrm{K}_{\mathrm{c}}$ that occur over a $2 \mathrm{hr}$ period in two of five experiments. In the depleted cells the ouabain-sensitive $\mathrm{Na}$ outflux and $\mathrm{K}$ influx are both lower than in the repleted cells, and the ratio of the amount by which the $\mathrm{Na}$ outflux fell as a result of depletion to the amount by which the $\mathrm{K}$ influx fell (1.19 and 1.16 in experiments I and II, respectively) was a little greater than one. Thus when $\mathrm{K}-\mathrm{K}$ exchange is eliminated, the response of the ouabain-sensitive $\mathrm{Na}$ outflux and of the ouabain-sensitive $\mathrm{K}$ influx to the removal of glucose is the same.

Stoichiometric coupling of the Na-K pump at a ratio of $3 \mathrm{Na}$ out to $2 \mathrm{~K}$ in requires that the ratio of ouabainsensitive $\mathrm{Na}$ outflux to ouabain sensitive $\mathrm{K}$ influx be 1.5 . The mean ratio for repleted cells from five experiments similar to those reported in Table II was $1.45 \pm 0.033$ (SE), which is not different from 1.5. However, the ratio for depleted cells in the same experiments was $1.83 \pm$ 0.16 (SE) but the variability was too great to permit evaluation of the significance of the deviation from 1.5. When the ratio of the fall in $\mathrm{Na}$ outflux due to depletion to the fall in $\mathrm{K}$ influx was calculated, the ratio was $1.31 \pm$ 0.06 (SE). It is uncertain that these deviations are significant; if they are, either of two mechanisms might account for them. First, it may be that, in depleted cells, a part of the $\mathrm{Na}$ outflux becomes uncoupled from the $\mathrm{K}$ influx. In this event, it should be possible to demonstrate a ouabain-sensitive $\mathrm{Na}$ outflux into $\mathrm{K}$-free solutions using depleted cells; such a flux could not, in fact, be demonstrated in either repleted or depleted cells. A second possible explanation is that the $\mathrm{Na} / \mathrm{K}$ coupling ratio is in some way dependent on the ATP concentration with more $\mathrm{Na}$ ions exchanged for each $\mathrm{K}$ ion in depleted cells; this possibility was not further evaluated.

On the basis of studies of the mechanism by which ouabain inhibits glycolysis in hemolysates containing membranes, Parker and Hoffman (14) suggested that ADP produced by the Na,K-ATPase may be compartmentalized within the membrane, and that this ADP is the substrate for membrane-bound PGK. Proverbio and Hoffman (15) have recently presented evidence which they interpret as indicating that the source of ATP for the $\mathrm{Na}, \mathrm{K}-\mathrm{ATPase}$ reaction comes preferentially from a membrane compartment. Feig et al. (6) proposed that ATP derived from the PGK reaction may be preferentially used for the active $\mathrm{Na}$ outflux since the ouabainsensitive $\mathrm{Na}$ outflux fell at a time when triose phosphate, the source of substrate for the PGK reaction, was low but the total intracellular ATP +2,3-DPG was still high. Since part of the red cell PGK is membrane bound (16), this would fit with the findings of Parker and Hoffman (14) and Proverbio and Hoffman (15). Since 
it is clear that only a fraction of the ATP consumed by the red cells is used for cation transport, there is no way of telling from the present experiments whether or not ATP from the PGK reaction is preferentially used by the pump. There is no basis, however, for believing that the source of ATP used for $\mathrm{Na}$ outflux is different from the source of that used for $\mathrm{K}$ influx, especially since the $\mathrm{Na}-\mathrm{K}$ pump is driven by intracellular ATP in reconstituted ghosts independent of the source reaction for ATP (17).

\section{REFERENCES}

1. Harris, E. J., and M. Maizels. 1951. The permeability of human erythrocytes to sodium. J. Physiol. (Lond.). 113: 506 .

2. Glynn, I. M. 1956. Sodium and potassium movements in human red cells. J. Physiol. (Lond.). 134: 278.

3. Post, R. L., and P. C. Jolly. 1957. The linkage of sodium, potassium and ammonium active transport across the human erythrocyte membrane. Biochim. Biophys. Acta. 25 : 118.

4. Sen, A. K., and R. L. Post. 1964. Stoichiometry and localization of adenosinetriphosphate-dependent sodium and potassium transport in the erythrocyte. J. Biol. Chem. 239: 345 .

5. Garrahan, P. J., and I. M. Glynn. 1967. The stoicheiometry of the sodium pump. J. Physiol. (Lond.). 192: 217.

6. Feig, S. A., G. B. Segel, S. B. Shohet, and D. G. Nathan. 1972. Energy metabolism in human erythrocytes. II. Effects of glucose depletion. J. Clin. Invest. $51: 1547$.
7. Post, R. L., and A. K. Sen. 1965. An enzymatic mechanism of active sodium and potassium transport. J. Histochem. Cytochem. 13: 105.

8. Glynn, I. M., and U. Lüthi. 1968. The relation between ouabain-sensitive potassium efflux and the hypothetical dephosphorylation step in the "transport ATPase" system. J. Gen. Physiol. $51:$ 385s.

9. Glynn, I. M., V. L. Lew, and U. Lüthi. 1970. Reversal of the potassium entry mechanism in red cells, with and without reversal of the entire pump cycle. J. Physiol. (Lond.). 207: 371.

10. Sachs, J. R. 1970. Sodium movements in the human red blood cell. J. Gen. Physiol. 56: 322.

11. Garrahan, P. J., and A. F. Rega. 1967. Cation loading of red blood cells. J. Physiol. (Lond.). 193: 459.

12. Lowry, O. H., J. V. Passonneau, F. X. Hasselberger, and D. W. Schultz. 1964. Effect of ischemia on known substrates and cofactors of the glycolytic pathway in brain. J. Biol. Chem. 239: 18.

13. Ussing, H. H. 1949. Active ion transport through isolated frog skin in the light of tracer studies. Acta Physiol. Scand. 17: 1.

14. Parker, J. C., and J. F. Hoffman. 1967. The role of membrane phosphoglycerate kinase in the control of glycolytic rate by active cation transport in human red blood cells. J. Gen. Physiol. 50: 893.

15. Proverbio, F., and J. F. Hoffman. 1972. Differential behavior of the Mg-ATPase and the Na, Mg-ATPase of human red cell ghosts. Fed. Proc. 31: 215.

16. Schrier, S. L. 1963. Studies of the metabolism of human erythrocyte membranes. J. Clin. Invest. 42: 756.

17. Hoffman, J. F. 1962. Cation transport and structure of the red cell plasma membrane. Circulation. 26: 1201. 